\title{
Articulações entre imagem e narrativa na Índia Antiga (A propósito da peça Uttararāmacaritam, de Bhavabhūti)
}

\author{
CARLOS ALBERTO DA FONSECA \\ Universidade de São Paulo
}

\begin{abstract}
RESUMO: Neste artigo pretende-se fazer uma exposição do diảlogo entre os registros imagético e narrativo no âmbito da cultura indiana mediante breve estudo da peça Uttararāmacaritam "O último feito de Rāma", de Bhavabhūti (séc. VIII d.C.). Particularmente intrigante em termos de sua carpintaria - quase evocando uma construção en abîme -, a peça coloca em cena os episódios finais do poema épico Rāmāyanạ, quais sejam as circunstâncias ligadas ao banimento de Sitā, grávida, esposa de Rāma, e ao encontro com seus dois filhos, ainda desconhecidos dele. O que torna interessante a dramatização dessa situação é que seu autor recorreu a registros variados de representação que se conjugam com o estatuto narrativo/teatral que estrutura a peça, na qual tudo se faz obliquamente, transversalmente: os fatos anteriores mais importantes são evocados através de painéis pintados que são visitados e "narrados" pelas personagens; além disso, o reconhecimento entre pai e filhos e o acerto final entre Rāma, Sìtā e Lakșmana se dá durante uma representação teatral escrita e dirigida por Vālmiki, que nada mais é do que o suposto autor do poema épico - numa sugestão bastante evidente da "teatralização" de uma certa Verdade sobre o discutido caráter de Rāma.
\end{abstract}

PALAVRAS-CHAVE: Literatura sânscrita; teatro sânscrito; Bhavabhūti; Uttararāmacaritam.

Uma das vertentes mais ricas da reflexão filo-religiosa da Índia antiga, presente de algum modo em todas as correntes de pensamento ali formuladas, diz respeito ao reconhecimento e ao estabelecimento da Verdade como fator orientador do sujeito na sua trajetória existencial. Em seu sentido mais literal, satya (termo que se costuma traduzir por "verdade" e "realidade") designa1 "tudo aquilo que pode ser/existir": a definição, a configuração possível do real/verdadeiro ficam por conta do sujeito, na dependência exclusiva de suas coordenadas ideológicas (o lugar que ocupa na sociedade, o tempo e o espaço em que vive, a educação a que teve acesso, suas pulsões/pulsações psicológicas, afetivas etc.) - o que quer dizer que sua "visão de mundo" sempre dependerá de sua $m \bar{a} y \bar{a}$, de sua "medida"2 das coisas, constatação que desembocará, em seus limites até mesmo políticos, nas questões da tolerância, da relatividade da existência, etc. (ou nos seus contrários).

Trata-se, em suma, de se perceber aqui, deste modo resumido, que a grande questão com que se debateram os indianos em sua vida diária e em sua reflexão sobre o estar-nomundo foi a da "representação", transplantada para a prática estética sob a forma da 
"semiose", ou seja, como construir um objeto que faça representar/significar uma certa Verdade, uma certa Imagem Medida sobre qualquer aspecto de tudo aquilo que possa ser tornado/considerado real. Foi esse o caminho trilhado pela literatura sânscrita (melhor dizendo: pela literatura indiana de expressão sânscrita) e, em especial, pela "representação dramática" (nātya) indiana, que nos interessa aqui particularmente.

Concebida e praticada, desde os textos mais antigos até agora encontrados (talvez os de Bhāsa, $c$. séc. II a.C.), como a possibilidade artística mais completa, e com a intenção básica de "ser vista" (toda peça é um drśyakāvya "obra literária para ser visível"), agencia a representação dramática - desde a preparação do texto até sua encenação - os mais variados recursos para a narração de uma história (itivrtta) que representa/imagina cenicamente um vastu (o tema, o $x$ da questão, o assunto fundamental do drama). Assim, a expressão verbal, a expressão corporal, a música, o canto, a maquiagem, os figurinos, o cenário, a mímica, a dança, a pantomima etc., e até mesmo produtos originados de outras práticas semiológicas como a pintura e a escultura, não como meros objetos de cena, mas como outras tantas "palavras criadoras" (brahman) - todos esses ingredientes são "amarrados" pelo dramaturgo, que os vai distribuindo em atos, nexos, prelúdios, temperando com emoções e os azeitando com entrejuntas, rodeios lingüístico-figurativos, torneios lingüístico-lógicos, figuras de linguagem etc. $\mathrm{O}$ trabalho dramatúrgico incorpora até mesmo as próprias formas de representação dramática conhecidas e praticadas, na forma de um metateatro sempre bem sucedido. Uma peça, por exemplo, como Mālavikāgnimitram ("Malaviká e o rei Agnimitra"), de Kālidāsa, séc. V a.C., apresenta a jovem Mālavikā cantando e dançando sua paixão pelo rei: uma forma de metateatro (com sua voz e seus movimentos ela está representando sua história afetiva com um objetivo em mente) que, a exemplo de tantas outras ocorrências, tem a intenção de fazer a narrativa seguir em frente; não se trata de uma dança-canção isolada: a personagem deve declarar seu amor, na seqüência dos eventos narrados, e o autor cria uma situação em que isso se torna possível, e necessário, para que a narrativa progrida.

Sempre, entretanto, com o zelo exacerbado da imposição ao texto dos limites miméticos a que o objetivo da "imitação/reconstrução do real" obriga ${ }^{3}$. É muito grande o peso que as "coisas da vida" (lokadharmin) exercem na fabulação dramática - mas ela se deixa atravessar por algumas convenções especificamente teatrais, as "coisas de teatro" (nātyadharmin) - como, por exemplo, a construção de personagens inexistentes na vida real (como o vidūṣaka "bufão"), a distribuição convencionalizada de registros lingüísticos diferentes entre as personagens, a quase completa ausência de cenário e sua presentificação nas próprias falas das personagens, etc.

Examinando-se, entretanto, a sequiência das peças teatrais elaboradas pelos dramaturgos indianos e procurando nela o lugar do Uttararāmacaritam de Bhavabhūti, são realmente dignas de nota as alterações introduzidas pelo autor no agenciamento dos recursos dramatúrgicos e teatrais que vinham sendo tradicionalmente utilizados: o Uttararāmacaritam de Bhavabhūti revoluciona profundamente a dramaturgia indiana clássica no sentido de explorar radicalmente certos procedimentos miméticos "de teatro" conhecidos mas muito pouco empregados - e por isso mesmo bastante incomuns - na tradição teatral indiana. Quer dizer: constitui-se num esforço inovador, experimental mesmo, de agenciamento dos mecanismos de representação, de criação de imagens, ou melhor, da proposta de "constru- 
ção de efeitos de sentido" (expressão com a qual se entende aqui o que foi proposto no título deste trabalho: "articulações entre imagem e representação").

Bhavabhūti, que deve ter vivido na primeira metade do século VIII d.C., é autor de outra peça, Mahāvīracaritam "O feito de Mahāvīra (= Rāma)", na qual resume a narrativa do épico Rāmāyaṇa do início até o livro VI, o penúltimo do poema - livro que termina, vale a pena lembrar, com a volta de Rāma para Ayodhyā (reino de onde havia sido banido) depois de sua vitória contra Rāvana e aparentemente sem mais qualquer dúvida a respeito de qualquer infidelidade conjugal de sua esposa Sìtā; trata-se de uma história de final feliz, com larga exploração do aspecto heróico do caráter de Rāma.

Na peça aqui em questão, seu autor retrabalha apenas o livro VII, o último, cujas leitura e credibilidade sempre foram tradicionalmente complicadas. A matéria narrada diz respeito ao banimento de Sītā por Rāma em função da pressão que o povo exerce sobre o governante com comentários a respeito daquela suspeita de infidelidade; expulsa pelo marido, e grávida, Sìtā vai morar na floresta de Pañcavațī, onde nascem os gêmeos Kuśa e Lava e onde ela morre; as crianças são criadas por Vālmīki, um erudito de vida ascética; por ocasião da realização de um ritual de consagração do poder real, Rāma termina por conhecer os filhos, reconhecer seus direitos, e a vida continua. Não, é claro, sem algum conflito interior: Rāma nunca terá plena certeza íntima da infidelidade/fidelidade da esposa nem da justiça/justeza da atitude que tomou contra ela. Como se pode perceber, há aí nesse livro um enredo perfeitamente plausível, com começo, meio e fim, perfeitamente recortável em unidades de tempo e espaço, que se pusesse a serviço da demonstração de um vastu que bem poderia ser "a inexorabilidade do ato praticado e todo seu cortejo de causas e efeitos" $\mathrm{e}$ ilustrado com uma narrativa em que personagens efetivas estivessem frente a frente como acontece com as pessoas "na vida" (mesmo que isso incluísse o maravilhoso/sobrenatural). O que acontece com o Uttararāmacaritam é que Bhavabhūti resolveu contar a história que faz o conteúdo do livro VII do Rāmāyaṇa do modo "mais teatral", de modo a quase sempre fugir do "estereótipo cênico", digamos assim, das formas já tradicionais em sua época de composição da cena e do enredo e a ensejar uma articulação renovada entre o que é ouvido/ dito/visto (a representação propriamente dita) e o efeito de sentido que pretende criar no palco (a imagem).

Para tanto, Bhavabhūti radicaliza um dos papéis fundamentais do dramaturgo, qual seja o de formador de opinião: parece introjetar em sua peça, como estratégia dramatúrgica, os conceitos de māya e de satya tal como discutidos pela escola filosófica Vedānta, de que era adepto e que tem como uma de suas maiores premissas a consideração de que a vida na terra é um verdadeiro inferno. A "vida cotidiana" se diz em sânscrito saṁsāra-que se pode interpretar literalmente como "onde tudo pode acontecer", mas também é como se diz naquela língua "caminhada sem rumo certo", "passagem por uma sucessão de estados diferentes", "motivo subjacente", "indecisão, o retorno sempre para um mesmo ponto". Qualquer um desses significados faz sentido na peça. Em outras palavras: Bhavabhūti conta a história de Rāma - porque é isso efetivamente o que se vê contado no palco -, mas não para nos demonstrar factualmente se Rāma teve ou não razão em ter agido como agiu com relação a Sìtā, mas para, usando esse enredo como pretexto, mostrar que a vida, o samisāra "onde tudo pode acontecer" é muito mais complicada do que parecem querer dizer nossos atos 
socializados, governados por contratos sociais: a consciência é o lugar primeiro onde ecoam e reverberam as questões. É importante ressaltar que, se Rāma sempre aparece marcado por alguma culpa com relação ao modo como agiu com relação a Sītā, também ela surge inquietada por algo errado que possa ter feito inadvertidamente e chega a pensar no suicídio como forma de reparação de seu erro - mas também Lakṣmaṇa, irmão de Rāma, tem sua parte nessa acareação: ele próprio diz ter agido/sido "sem-vergonha" (nirlajja) com relação à cunhada. Não interessa determinar com qualquer grau de imparcialidade se Rāma fez o que fez por ciúme infundado ou não, se Sītā o traiu efetivamente ou não, se Lakṣmaṇa assediou a cunhada ou não. Em outras palavras: não parece ser o objetivo de Bhavabhūti a definir com clareza qualquer culpa ou culpados: ele parece interessado em propor cenicamente o próprio torvelinho da dúvida, o próprio furacão da indecisão - e isso estaria alegorizando a complexidade do viver o dia-a-dia.

Tudo se faz obliquamente, transversalmente - começando com a própria linguagem verbal e o ritmo arrastado que ela imprime à narrativa. Trata-se, sem dúvida, de uma das peças mais longas do teatro indiano clássico, e feita de eventos mínimos, mas dilatados pela palavra, que os cerca e os amplia em frases e estrofes que ecoam em um e outro ato, reatando fios e retecendo alguns motivos. Momentos de lucidez e de rememoração (retomada da consciência) alternam com momentos de total dissolução dos sentidos em meio a uma experimentação dramatúrgica que vale a pena detalhar.

O prólogo da peça não deixa segredos: adianta com toda clareza que está sendo preparada a coroação festiva de Rāma, que voltou do exílio com a esposa - e um ator da companhia lembra a "gravidez avançada da filha de Janaka (= Sìtā)" (kațhoragarbhām jānakìm). Referindo uma louvação a ser feita ao soberano, o diretor da peça amarra numa mesma expressão a desconfiança sobre o valor das palavras e sobre a virtude de Sìtā, que não está isenta de censura, afirmando ainda que a humanidade é mesmo malvada quando se trata da virtude das palavras e das mulheres ${ }^{5}$. Ao que acrescenta o ator, dando a chave para a compreensão do conflito interior de Rāma: "as pessoas murmuram sobre a rainha Sītā; sua estada na casa de Rāvaṇa é o motivo, embora a prova do fogo as faça duvidar" ". Concluindo a indiciação dos motivos dramáticos da peça, o diretor afirma: "se esse rumor chegar novamente ao rei, provavelmente acontecerá uma desgraça"’

Os atos I e II cumprem a função do "nexo de apresentação". Na primeira sequiência do ato I, Rāma e Sìtā percorrem, com Lakșmaṇa, uma galeria de pinturas que representam todas as façanhas de Rāma em sua aventura contra Rāvaṇa [o Tormento, alegoria das suspeitas de Rāma, personificado já no poema épico como seu inimigo e chefe de um exército de inimigos] até o momento da purificação da rainha no fogo [modo de fazer representar, no texto épico, o fato de Rāma se conformar com a idéia da fidelidade de sua esposa]. As falas das personagens não descrevem os quadros: fazem apenas alusões a episódios - mas são suficientes para evocar na memória de espectadores que já conheciam a história todo o seu desenrolar.

A dramaturgia transversal começa aqui: numa forma tradicional de efabulação, o conteúdo dos quadros seria revelado pelo diálogo de personagens; em outras palavras, seria narrado por personagens - ou, de outro modo, o autor poderia perfeitamente ter construído uma outra cena, com outra mobília dramatúrgica: esses quadros no cenário e na fala das 
personagens não são absolutamente necessários para que o enredo se instale. Mas ocorre que Bhavabhūti os utiliza como "entrejuntas", "nexos internos" (antarasamidhi), elementos da carpintaria dramatúrgico-teatral encarregados de dar consistência à construção. Sua utilização deve ter algum sentido. E, com efeito, com eles o autor parece querer dizer, no fundo, com os quadros em cena e referidos elipticamente, que já existe uma certa visão cristalizada a respeito de Rāma concretizada no discurso figurativo desses quadros; já existe uma certa heroicidade reconhecida pela sociedade - uma heroicidade relativa ao plano público de sua vida. Em outros termos: eles fornecem, expressam, uma certa $m \bar{a} y \bar{a}$ social, coletiva, a respeito de Rāma; instauram uma certa percepção de um satya, uma verdade relativa ao rei. Dizendo de outro modo, ainda: a cena - três personagens visitando uma exposição de cerca de 20 quadros (a única ação cênica) - constrói o sentido de heroicidade, não a partir da narrativa dos atos heróicos de Rāma, mas a partir da consagração desses atos num discurso pictórico já socializado.

Imagem, entretanto, que o autor torna complexa logo em seguida, na segunda seqüência, acrescentando-lhe a crueldade, quando Rāma, estando Sītā adormecida em seus braços, não hesita um segundo em bani-la para a floresta em função do relato que lhe faz um espião a respeito dos murmúrios que circulam entre o povo, ordenando ainda que Lakṣmaṇa, o irmão supostamente infiel, acompanhe a rainha até o local do exílio. Corroendo-se de ciúme, raiva e desespero, Rāma sai, chorando; logo a seguir Sītā desperta e diz que teve um "mau sonho" (duhsvapna) no qual estava separada do marido - situação que nos faz reler toda a sequiência como uma representação dos temores da própria Sītā com relação ao povo e a essa nova viagem em companhia do cunhado e os novos rumores que ela poderia desencadear. Situação inusitada, em comparação com o épico, no qual Sītā jamais se amedronta nem diz qualquer coisa que pudesse fazer pensar num reconhecimento de alguma inclinação de sentimentos com relação ao cunhado: na peça penetramos nos meandros afetivos, morais e psicológicos de Sītā - da qual ficamos com uma outra māyā, um outro satya. E também de Rāma, agora um sujeito capaz de ódio e crueldade no plano privado.

Nessa cena não se está exatamente diante de um dos muitos sonhos proféticos comuns nas peças do teatro sânscrito: trata-se aqui de um estratagema dramatúrgico que diz/ representa aquilo que nunca veremos sendo dito por Sìtā em momento algum: essa cena, que termina com o espião (paricārakin; e não é sem importância o fato de ele se chamar Durmukha, lit. "Boca Ruim") conduzindo a rainha para o carro arranjado pelo cunhado, apresentando/representando os meandros mentais e psicológicos de Sītā, constrói os efeitos de sentido da crueldade de Rāma e do reconhecimento de culpabilidade no caso de Sìtā. Com relação a Lakșmaṇa, ele continua merecendo o respeito do irmão, mas continua se esquivando nos desvãos da narrativa.

No ato II, continuando a "apresentação", passamos ao Rāma público. Doze anos depois das cenas do ato I, Rāma está na floresta de Pañcavațī, exatamente onde ele e Sītā viveram felizes durante os primeiros anos do exílio de Ayodhyā, antes que esta história toda acontecesse, e para onde Sìtā foi banida.

No prelúdio desse ato, a asceta Ātreȳ̄ e uma divindade da floresta resumem os acontecimentos: Kuśa e Lava, os filhos gêmeos de Sītā e Rāma, agora com cerca de doze anos de idade, foram criados e educados por Vālmīki, que foi encarregado de compor um Ràmāyana 
(quer dizer: agora já existe um discurso literário oficial - uma māyā, um satya - sobre Rāma); nada se sabe sobre Sītā, mas fica-se sabendo que Rāma mandou instalar uma estátua de ouro da esposa em seu palácio (uma māyā, um satya - sobre Sìtā) - dado bastante expressivo e sintomático do estado mental e afetivo de Rāma. Lembram, ainda, as ascetas que Śambūka, um xudra que leva vida de asceta, deve ser decapitado por Rāma por não estar vivendo conforme o dharma de sua casta e, com isso, ter causado a morte do filho de um brâmane: a morte do xudra devolverá a vida ao garoto, isto é, recobrará a ordem no mundo com a pacificação de todas as mentes. É preciso lembrar que o termo śambūka, como substantivo comum, designa um molusco bivalve aquático - animal que não deverá sobreviver, por uma lei da natureza, se colocado num ambiente diferente. Em outros termos: acredita-se que o desvio de comportamento social por parte do xudra causou a morte do pequeno brâmane e que o rei, por sua onipotência e seu senso de justiça divinos, poderá restabelecer o equilíbrio universal.

Tem início, então, o ato II propriamente dito. Mal entrando em cena, Rāma degola Śambūka, o xudra referido no prelúdio. Mas acontece que Rāma degola o xudra "aniquilado pela compaixão" (sadaya) e, quando o golpeia, ele o faz "com repugnância" (kathamicit prahrtya) - em nada parecido com o frio Rāma do poema épico. Não deixa de haver, aqui, o reforço daquela $m \bar{a} y \bar{a}$ heróica, daquele satya heróico, a respeito do Rāma público - mas esse rei não parece estar eliminando do mundo dos vivos alguém que rompeu a ordem universal, mas tão só e simplesmente um ser humano de muito poucos poderes de qualquer espécie. Rāma, o mesmo marido que, doze anos atrás, não hesitara em desterrar a esposa grávida, agora manifesta uma grande hesitação no cumprimento de seu dever enquanto rei. Sentimentos tão opostos, relativos a esferas de comportamento tão opostas, terminam por compor um Rāma completamente desordenado. Para isso com toda certeza concorre também o décallage temporal: duas cenas tão próximas no tempo teatral, duas cenas com um intervalo entre si de doze anos no tempo dramático: eis aí um dado importante para a construção do efeito de sentido de desordenação completa que se vai instaurando.

As cenas seguintes do mesmo ato reforçam essa desordem: desembainhando sua espada, Rāma degola Śambūka, que imediatamente se transforma num ser sobrenatural que leva Rāma, num longo passeio pelos ares, de uma floresta para outra - uma figuração de um devaneio de Rāma -, uma viagem que chega à floresta de Dandakā (onde ocorreram alguns dos episódios da luta de Rāma contra prepostos de Rāvaṇa) e de novo o traz para Pañcavațī - numa alusão representada teatralmente do conflito interior de Rāma, alusão que termina com uma descrição da floresta - agora sem as flores e os perfumes e as brisas suaves e as aves gentis de antes, mas habitada por corujas, gralhas, pavões gritadores, serpentes, grutas, cumes de montanhas envoltos em nuvens, e que termina nas ondas tumultuosas do mar - e aqui também o cenário explicitado nas falas das personagens concorre para a criação do sentido/clima.

O que aconteceu, efetivamente, até aqui, nos atos I e II, caracterizados como a "apresentação" do assunto? No plano do comportamento público, num certo dia o rei Rāma teve sua heroicidade afirmada (discurso pictórico do ato I), e reafirmada doze anos depois (discurso literário do prelúdio ao ato II) - mas o episódio da degola do xudra diminui esse caráter. No plano do comportamento privado, num certo dia o marido Rāma expulsou a 
esposa grávida - mas seria possível pensar que o xudra degolado é uma representação dessa esposa, ambos vivendo fora do seu ambiente. Tanto as pinturas da galeria quanto a narrativa composta por Vālmīki são parciais - tanto no sentido cronológico (relatam apenas os feitos de Rāma até a volta do exílio) quanto no sentido ideológico (elas enaltecem o personagem, louvando-lhe o heroísmo - o ter feito o que tinha de ser feito: após degolar o xudra, Rāma diz: krtam rāmasadŕśam karmal "feito! um ato como convém a Rāma"). Mas a peça vai mostrando o lado sombrio das questões íntimas, clareando-as com a construção do descontrole de Rāma. A māyā, o satya sobre o personagem estão sofrendo modificações. Note-se, entretanto, que o irmão Lakṣmaṇa continua ausente, em silêncio - o que pode ser a construção de algum sentido para a atuação desse personagem nessa história.

O ato III corresponde ao "nexo da continuação". No seu prelúdio, no mesmo cenário do ato anterior, as águas dos rios Muralā ("Constrangimento") e Tamasā ("Trevas"), antropomorfizadas como seres femininos, referem o alquebramento físico e moral de Rāma e informam que, por obra divina, Sītā, que está morta, voltará, invisível, para consolar o rei. No ato propriamente dito, numa sequiência povoada apenas por personagens espectrais, Sìtā conversa com esses rios e colhe flores; lembrando-se do marido, desmaia, recobrando os sentidos quando ouve uma voz dizer que Rāma, em carne e osso, está chegando; ao vê-lo, desmaia novamente, abraçando Trevas; Rāma, vendo essa floresta que lhe traz tão boas recordações de instantes amorosos ali vividos com Sītā, também perde os sentidos; Sìtā, voltando a si, e ordenada pela mesma Trevas, acaricia, chorosa, Rāma, que, tocado pelo frescor das mãos de Sītā, recobra a consciência; segue-se um diálogo entre os dois, cortado por falas dos rios - mas trata-se de um diálogo que a muito custo adquire sentido uma vez que cada um está falando consigo mesmo e durante o qual ambos demonstram forte abatimento físico e soluçam e lacrimejam. Num determinado momento, recobrando-se de um desmaio, Sītā aproxima-se precipitadamente e coloca suas mãos sobre o coração e a fronte de Rāma, que saúda com alegria o rio Constrangimento, para logo em seguida cerrar os olhos novamente. Ouvindo a voz do rio Constrangimento, que julga ser a de Sītā, Rāma a abraça, ao que o rio grita "Desgraça! Isto é loucura!" (kaștam unmāda eva).

Logo depois, Rāma se pergunta se não estaria sonhando (na cāsmi suptaḥ) e afirma que o "bem-aventurado Engano", que o segue outra vez, criado por ele, (bhagavānanekavāraparikalpanānirmito vipralambhah punah punaranubadhnāti mām), é a origem de seu sonho. Ao que Sītā, ouvindo o pensamento de Rāma, afirma: "eu, verdadeiramente cruel, engano meu nobre marido" (mayaiva dārunayā vipralabdha āryaputraḥ). Logo depois Rāma sai, não sem antes dizer que providenciará uma imagem de Sītā em ouro para representá-la durante a realização do sacrifício do cavalo, destinado a remarcar o poder real (e agora um discurso escultórico oficial...).

I. Quadros não-verdadeiros, II. onipotência-devaneio, III. alucinação amorosoremorsal...

Os atos IV e V cumprem a função da introdução da intriga (ou episódio) paralela, que funcionará como coadjuvante da narrativa, e configuram o "nexo da complicação".

No prelúdio ao ato IV, dois ascetas muito jovens, Dāṇḍāyana e Saudhātaki, referem a chegada de hóspedes ilustres ao eremitério de Vālmīki. No ato propriamente dito, os hóspedes Kausalyā (mãe de Rāma) e Janaka (pai de Sītā) conversam com Arundhatī, 
esposa de Vasisțha, um antigo mestre de Rāma. Todos lamentam, ainda doze anos depois, o desfecho da história de Rāma e Sītā, ouvem vozes de crianças brincando do lado de fora, sentem-se atraídos pela figura de um dos meninos, que acaba entrando na sala: é Lava. As mulheres agem muito familiarmente (pegam-no no colo ou o abraçam - utsange grhītvā), inquirem o garoto, que diz saber de si apenas que pertence à família do sábio Vālmīki, por quem foi criado. Alguém diz que o pequeno príncipe Candraketu, filho de Lakșmaṇa, proibiu que qualquer pessoa adentrasse o eremitério, como parte dos preparativos do sacrifício do cavalo - ao que Lava declina os nomes dos pais do menino Candraketu, o que desperta grande curiosidade nos hóspedes. Inquirido sobre a razão de, apesar de morar na floresta e viver afastado dos acontecimentos da corte, ele conhecer o príncipe Candraketu e os nomes dos pais do garoto, Lava revela a existência de partes de um poema sobre a vida de Rāma que já foram compostas (pragìta "cantaroladas"; o termo remete à produção e à transmissão orais) por Vālmīki mas ainda não divulgadas e de outras partes que nem ele mesmo conhece - e de uma outra "própria para ser representada" (abhineyārthakrta) e que não the foi revelada pelo velho eremita. O menino refere, ainda, o ponto final da narrativa que conhece: "estando o rei preocupado por causa da censura dos cidadãos com relação a uma falsidade, Lakṣmaṇa abandonou Sītā na floresta, sozinha, com as dores do parto já próximas, e voltou"s. Kausalyā se pergunta "qual culminação do jogo cruel da vida foi agora lançada sobre Sītā, a corpo-lótus, sozinha..." (ka idānīm te śarīrakusumasya [...] daivadurvilāsapariṇāma ekākinyā nipatitas), Janaka lamenta tanto "a maldade dos cidadãos" (aho nirdayatā durātmanāim paurānāàm) quanto "o ato precipitado do rei Rāma" (aho rāmasya rājñah kṣiprakāritā). Arundhatī, como que chamando à consciência o velho rei consternado, reafirma a ordem das coisas: "Rei, Rāma é teu filho, e protegido deve ser o povo miserável" (rājan napatyam rāmas te pālyāś ca krpaṇa janāh).

Quer dizer: todas as personagens em cena conhecem a mesma história, até o mesmo ponto, mas de um ponto de observação diferente. Por um lado, a mãe de Rāma e o pai de Sìtā ainda não se conformaram com seu desfecho, que nem sabem qual terá sido; por outro, sem julgar a história com razões ditadas por seu coração, a esposa do mestre acredita que o que aconteceu já aconteceu e a vida continuou. Talvez o poema referido pelo menino revele alguma coisa... Em meio a uma grande consternação, os três velhos se apresentam ao menino, sem dizer quem realmente são com relação a ele, que ignora ser filho de Rāma, circunstância também ignorada pelos três velhos. Em outras palavras: as personagens estão todas próximas, ocupando o mesmo espaço, mas não cumprem o sentido existencial que se esperaria normalmente de personagens com seu estatuto familiar. Entram outras crianças e Lava sai com elas discutindo regras do sacrifício do cavalo e mostrando conhecimento com grande presunção.

Bhavabhūti parece estar aqui testando os limites das cenas de reconhecimento tão comuns em vários gêneros de peças dessa tradição teatral, mas que se resolvem num segundo: aqui o garoto, que conhece grande parte da história, ignora apenas qual seu verdadeiro papel; os velhos conhecem outra parte da história, e seu coração os trai; por outro lado, nenhum espectador ignora qualquer dado. Uma pequena comédia de erros, uma farsa tratada em chave dramática: bastaria uma palavra e tudo se resolveria. 
$\mathrm{O}$ autor, porém, mantém suspenso o desenlace: no ato $\mathrm{V}$, a rivalidade das crianças se concretiza: num carro de guerra, Candraketu percebe a beleza, a força e a habilidade de Lava no comando de seu bando e o desafia para um duelo; Lava se apresenta, mas volta para a cena do combate, preparando-se para usar as armas Jṛmbhaka ("desabrochar, escancaramento") - atitude que deixa Candraketu absolutamente espantado: é aceitável que Lava tenha aprendido o manejo dessas armas mágicas com Vālmīki, mas elas pertenciam a seu tio Rāma, a quem foram dadas pelo sábio Viśvāmitra quando Rāma era adolescente - o que estariam elas fazendo nas mãos daquele desconhecido? Alguma coisa acontece no coração dos dois meninos, e, num instante mágico, quando parece que tudo fica parado e silencioso, eles dizem, ao mesmo tempo, para si mesmos e cada um sobre o outro: "Que nobre aparência tem esse príncipe! (aho priyadarçanah kumārah) /.../ Como poderei lançar minhas flechas contra ele se quando me aproximo minha disposição é abraçá-lo?" (moktavyāh katham iva sāyakāh śarīre yatprāptau mama parirambhanāmilāṣād unmīlat). O auriga de Candraketu também se põe estranhamente inquieto, seus olhos ficam úmidos - mas logo os dois meninos acabam se desentendendo novamente, Candraketu chama Lava de soberbo e uma nova disputa entre os dois se insinua, agora com a probabilidade de ser ainda mais violenta. Dentro daquela mesma comédia de erros, avança-se um passo na questão do reconhecimento - mas ele ainda não se efetiva.

O ato VI corresponde ao "nexo da crise". No prelúdio, um casal de semidivindades relata o combate entre os meninos: Candraketu e sua "arma do fogo" (agnicchat $\bar{a}$ ) versus Lava e sua "arma aquática" (vāruṇāstra). Percebendo a chegada de Rāma (que acabou de matar o xudra Śambūka - e então se percebe que as ações dos atos II e III são em grande medida simultâneas às ações dos atos IV e V), os meninos interrompem a disputa, justamente no momento em que Candraketu usava sua "arma do vento" (vāyavyāstra) - uma luta entre os elementos... No ato propriamente dito, Candraketu, chamando Rāma de tāta "paizinho" (ambos são tio e sobrinho, mas o código de etiqueta dos xátria exige essa forma de tratamento), apresenta-lhe seu valente contendor, referindo-se a Lava como um "companheiro de percurso" (vayasya) - o que permite também a Lava chamar Rāma de tāta. Lava acaba revelando ser discípulo de Vālmīki, o que aumenta a boa impressão que o garoto causara no príncipe, admiração que cresce ainda mais quando Candraketu relata o uso das armas J̦̣mbhaka por Lava. Rāma abraça o menino, chamando-o de "filho" (vatsa), o que deixa o garoto intrigado com tanta ternura. No relato de sua educação, Lava acaba contando que tem um irmão gêmeo, Kuśa, que adentra o salão. À vista do comportamento arrogantemente seguro dos dois irmãos e de sua beleza, Rāma termina por considerar que deve lhes fazer uma pergunta mais concreta, que responda às suas inquietações; murmura para si mesmo "ingênuo coração! o que é esta inesperada ternura que te agita e te altera?" (mugdhahṛdaya ko 'yamākasmikaste pāriplavo vikārah) e imagina, dissimulando sua angústia, ouvir partes do Rāmāyana contadas pelos meninos, que recitam alguns versos, lembrando Rāma outros; sua angústia vai aumentando - mas seu coração é poupado por uma voz que avisa que os hóspedes estão chegando, e então saem todos para os saudar. E a solução de tudo fica novamente adiada...

Esses três atos parecem configurar um longo "ato (cênico) falhado"...: há um reconhecimento que parece poder se concretizar a qualquer instante - como estava acostumada 
a tradição teatral. Um reconhecimento tão longamente preparado, com toda probabilidade o mais extenso em todo o repertório teatral sânscrito. O que pretendeu seu autor com essas cenas? Todas as personagens sabem - pelo coração ou por informação, em maior ou menor medida - quem são as pessoas que participam desse jogo. E por onde é que anda Lakṣmaṇa - o terceiro lado desse triângulo amoroso nunca explicitado no discurso de qualquer personagem? Nesse prolongamento do suspense estaria ocultada a possibilidade de, feito o reconhecimento, ficar claro que os meninos são mesmo filhos de Rāma e, nesse caso, incorrer-se numa mentira?

O ato VII corresponde ao "nexo da resolução". No seu prelúdio, Lakṣmaṇa informa que todos, mortais e imortais, estão a postos para a representação da obra de Vālmīki (para os espectadores do Uttararāmacaritam há aí uma informação subjacente: o que se vai ver representado faz parte daquele conteúdo da narrativa já composta por Vālmīki que ainda não foi divulgado a ninguém e ao qual se referiu o menino Lava); Rāma entra e, dentro do prelúdio do ato VII, tem início o prólogo da peça de Vālmīki, que é uma redução ao mínimo do esquema formal de todos os prólogos de todas as peças teatrais indianas: uma fala do diretor de cena pedindo a atenção de todos para o que se vai ver, uma fala de Rāma na platéia (reconhecendo o caráter de verdade da palavra de um sábio), uma fala de Sìtā nos bastidores (com o parto se aproximando, pedindo socorro a um Lakșmaṇa personagem-dosbastidores e dizendo que vai se atirar ao rio), uma fala de Lakṣmana personagem-da-platéia ("desgraça! mas isto é inesperado!" [kaștam vatanyadeva kimapi] - grito que revela o total desconhecimento que se tinha do que aconteceu a Sìtā quando ela foi abandonada na floresta) e uma nova fala do diretor de cena, relatando que Sìtā, filha da Terra, vai se entregar às águas do Ganges. Termina o prólogo da peça, que coincide com o fim mesmo do prelúdio do ato VII - dado que não pode de modo algum ser ignorado ou desconsiderado.

O ato VII propriamente dito, que corresponde ao corpo integral da peça de Vālmīki, precisa ser dividido em pelo menos seis seções para uma apresentação mais didática de seu enredo.

Na seção A, Rāma, na platéia, emocionado com o que acabou de ouvir sendo dito no palco, grita "Rainha! Rainha! Lakṣmaṇa, olha!" - ao que o irmão - ainda com noção clara da existência de dois espaços - lembra que aquilo que estão vendo e ouvindo "é apenas uma peça teatral" (nātikam idam); Rāma/espectador continua perturbado, agora dirigindo-se à própria Sītā/personagem, reconhecendo que a desgraça que aconteceu a ela se deu por sua culpa - ao que, novamente, Lakṣmaṇa o lembra de que deve continuar vendo o espetáculo (drśyatā), com o que Rāma prontamente concorda (eșa sajjo 'smi vajramayah "estou preparado, duro [lit. "feito de diamante"]).

A seção B se inicia com a entrada de Sītā, sustentada pelas deusas Terra e Ganges, cada uma delas carregando um menino. A reação de Rāma é sentir que está "entrando numa grande escuridão" (andhatamasam iva praviśāmi) - que tanto pode ser uma confusão mental quanto um desfalecimento físico. A cena continua, num diálogo entre as deusas e a rainha - esta quer abandonar as crianças, as deusas estabelecem que elas vão ficar com Vālmīki; Sītā quer atirar-se aos braços da mãe Terra - diálogo que é interrompido várias vezes, mas brevemente, para que Lakșmaṇa/espectador felicite Rāma pelo nascimento dos filhos, pela proteção dada pela Terra e pelo Ganges, para Rāma reconhecer o "patético" 
(karuna) de toda a história (khalv etat karunottaram vartatel "com efeito, isto está se tornando sumamente patético").

Tem início a seção C, com um ruído: na peça, ou na peça dentro da peça? Rāma/ espectador estranha, Sītā/personagem também, as deusas Terra e Ganges dizem tratar-se da manifestação das armas Jṛmbhaka; Sìtā conversa com as deusas sobre abandonar os filhos, é convencida a aguardar o desmame dos meninos para então fazer o que quiser. As três saem, Rāma/espectador se desespera com o pressentimento da morte de Sītā/personagem e desmaia. Lakșmaṇa /espectador acorre, perguntando a Vālmīki se este - o desfalecimento de Rāma? - era o assunto da peça.

Na seção E, uma voz nos bastidores anuncia um "prodígio extraordinário" (abhyanujñātam pavitram) logo referido por Lakṣmaṇa: Sītā, Ganges e a Terra saem da água; outra voz nos bastidores diz a Arundhatī/espectadora que "te entregamos Sìtā, casta esposa" (arpiteyaṁ tavāvābhyāim sītā puṇyavratā vadhūḥ); Arundhatī entra - e quem seria essa Arundhatî: uma personagem da peça na peça ou a mesma personagem que já apareceu na peça? - e Sītā/personagem toca Rāma/espectador, pedindo-lhe que volte a si; Rāma recobra os sentidos, reconhece todos; reconhece seu erro (katham krtamahāparädho bhagavatībhyām anukampitah/ "como eu, culpado de tão grande erro, sou merecedor da piedade dessas deusas?") e se inclina, arrependido; ao que Arundhatī, numa fala que ultrapassa a peça na peça, a peça e a platéia de ambas, parece dirigir-se a todo o mundo": "Ouvi, vós da cidade e do campo: aquela que é pelo Ganges e pela Terra louvada, que foi entregue a mim, Arundhatī, e cuja pureza de conduta o bem-aventurado Agni há algum tempo reconheceu; aquela que é elogiada pelos deuses, inclusive Brahman, e também pelos brâmanes; aquela que se casou com a dinastia solar - Sītā, que nasceu no lugar do sacrifício, ela deve ser aceita? O que dizeis agora, pessoas respeitáveis?"

A quem se dirige esse discurso-apenas-pergunta: aos espectadores da peça que se foi comentando até aqui, e que agora agem como personagens da peça a que eles próprios estavam assistindo? Agora já ninguém mais é apenas personagem ou apenas espectador: entraram todos numa outra dimensão em que mortos e vivos, inocentes e culpados, agentes ativos e passivos dessa história estão frente a frente. Lakșmaṇa se inclina diante de Sītā, representando todas as criaturas em sua homenagem. Arundhatī dirige-se a Rāma, pedindolhe que coloque a verdadeira Sītā - mas como, se ela está morta? - no lugar da imagem de ouro que mandou esculpir. Lakșmaṇa inclina-se novamente diante de Sītā, dizendo-se "impudico" (nirlajja, lit. "sem-vergonha"). Arundhatī pede a Vālmīki que traga as crianças, o que provoca extrema alegria em Rāma e Sītā...

Na seção F, Vālmīki entra com Kuśa e Lava, vindo pelo palco da peça, e acontecem as apresentações: cena de regozijo geral (pai! mãe! avô!), os meninos dizem "somos felizes" (dhanyau svah), Sītā (uma atriz, e não a verdadeira!) diz "aqui estou em plena felicidade" (nirbharāsmyānandena).

Logo vem a bênção final, proferida por Rāma, da qual se pode destacar: "[este relato] é o sentimento na forma da representação teatral dirigida aos experts" ([kathā] tām etām paribhāvayantvaminayairvinyastarūpam budhāḥ].

E é este seu Rāmāyaṇa, dirigido aos experts, que Bhavabhūti recoloca no lugar do outro... Quer dizer, a peça propicia o desmonte e a remontagem da imagem de um Rāma 
- que se tradicionalizava institucionalmente - com a inclusão, como dado estrutural de sua personalidade, dos elementos que conflituavam sua consciência: reconhecimento da sua impotência e de sua fragilidade (ou pelo menos de uma potência problematizada) tanto em questões públicas quanto em questões privadas - e isto sempre proposto teatralmente na forma de uma narrativa que explora novidades (ou radicalizações) na construção cênica de narrativas: cenas (metateatro dos quadros, comédia de erros, alegorias dos devaneios e das alucinações, reconhecimento que não se concretiza e nem é solução, o rompimento da quarta-parede) cuja seqüência provoca choques, cria "efeitos de sentido" opostos ou contraditórios - mas que se somam para instituir, pensando-se na vida, no samsāra, um outro Rāma - um sujeito conflituoso, exatamente igual a qualquer ser humano, e não mais - ou não mais apenas - o deus Rāma, o herói Rāma. É claro que se pode falar que se, com Vālmīki, no poema épico Rāmāyaṇa, a história de Rāma foi literarizada, ganhou estatuto literário, com Bhavabhūti, em Uttararāmacaritam, ela foi teatralizada, ganhou estatuto teatral (as cenas de metateatro e as cenas de concepção cênica renovada não cumprem a função tradicional de fazer a progressão da narrativa: elas são a própria narrativa). Mas pode-se dizer, também, que ela foi transcendida: seu autor parece querer dizer que não é exatamente o teatro que re-presenta a vida, mas é a própria vida que se organiza como um grande espetáculo teatral.

\section{Notas}

1 - A palavra é formada do particípio presente de AS "ser" (sat) sufixada com o morfema ya de sentido gerundivo; pode significar, na literalidade de sua morfologia, "o sendo", "o sível".

2 - Tradução literal do termo. Geralmente traduzido como "ilusão", pode ser entendido como "ilusão referencial dos sentidos", "ponto-de-vista de um indivíduo que depende de sua grade de conhecimento". A palavra deriva de MA "medir".

3 - Segundo a definição de Bharata, autor do Bhāratanātyaśāstra, séc. II d.C., o mais antigo tratado sobre o teatro na Índia antiga, "o nātya é a reprodução do comportamento das pessoas" (lokavrttānukaranam nātyam) [ou a repetição dos processos do mundo...]

4 - Lit. "aquele que elimina (problemas) de todos os modos"; uma tradução mais adequada seria "Quebra-galho".

5 - savethā vyavahartavyam kuto hyavacanīyatā/ yathā strīnām tathā vācām sādhutve durjano janah/ I "por mais perfeita que fosse feita, como ser incensurável? sobre a virtude das palavras e sobre a das mulheres os homens são malvados".

6 - devyām api vaidehyām sāpavādo yato janaḥ/ rakṣog̣̣hasthitir mūlam agniçuddhau tvaniścayaḥ//

7 - yadi punar iyah kim vadantī mahārājam prati syandeta tataḥ kaștam syāt//

8 - alīkapaurāpavādadvignena rājñā nirvāsitām [...] sītām āsannaprasavavedanām ekākinīm araṇye lakșmanah parityajya pratinivịtta iti//

9 - bho bhoh paurajānapadāḥ/ iyam adhunā bhagavatībhyām vasundharājāhnavībhyām evam praśasyamānā mamārundhatyāḥ samarpitā pūrvam ca bhagavatā vaiśvānareṇa nirṇītapuṇyajāritrā sabrahmakaiś ca devaiḥ samintutā sāvitrakulavadhūrdevayajanasambhavā sītādevī parigṛhmatām iti katham iha bhavanto manyante// 


\section{Referências bibliográficas}

BHAVABHŪTI, El último lance de Rāma. Texto sânscrito, introdução e tradução de Juan Miguel de Mora. Notas de Marja Ludwika Jarocka. México: UNAM, 1984.

FONSECA, C. A. Articulations entre l'image et le récit dans l'Inde ancienne (sur la pièce Uttararāmacaritam, de Bhavabhūti). Classica, São Paulo, 13/14, p. 261-273, 2000/2001.

RÉSUMÉ: Cet exposé a pour but de présenter le dialogue entre le registre des images et celui du récit dans le cadre de la culture indienne par une brève étude de la pièce Uttararāmacaritam "Le dernier exploit de Rāma", de Bhavabhūti (VIII'. s. apr. J.-C.). Particulièrement curieuse en ce qui concerne la composition - elle fait penser à la mise en abîme - la pièce met en scène les derniers épisodes du poème épique Rāmāyanạ, c'est-à-dire, les circonstances qui ont trait au baniment de Sitāa, enceinte, la femme de Rāma, et à la rencontre de ses deux enfants, encore inconnus de lui. Ce qui rend très intéressante la dramatisation de cette situation est le fait que son auteur fait appel à des registres multiples de mise en scène les conjugant au statut récit/ théātre qui organise la pièce où tout se passe de manière oblique, transversale: les événements antérieurs les plus importants sont évoqués par des tableaux peints qui sont vus et "racontés" par les personnages; en plus, la rencontre du père et de ses enfants ainsi que l'accord final entre Rāma, son épouse Sìtā e son frère Laksmanana ont lieu pendant la représentation d'une pièce de théātre écrite et mise en scène par Vālmìki, qui est tout simplement l'auteur supposé du poème épique - dans une allusion assez évidente de la "théatralité" d'une certaine Vérité sur le caractère discutable de Rāma.

MOTS-CLÉS: Littérature sanscrite; théātre sanscrit; Bhavabhūti; Uttararāmacaritam. 